УДК: 657.631.6

JEL Classification: M 42

\author{
O. М. ПІВНЬОВА, \\ магістрант, \\ спеціальність "Облік і оподаткування", \\ Національна академія статистики, обліку та аудиту; \\ Науковий керівник: \\ О. Е. Лубенченко, \\ кандидат економічних наук, дочент, \\ завідувач Національного иентру обліку та аудиту, \\ Національна академія статистики, обліку та аудиту
}

\title{
Міжнародні стандарти фінансової звітності та знецінення фінансових активів на прикладі КП “Луганський обласний фонд підтримки індивідуального житлового будівництва на селі”
}

В статті розглянуто особливості відображення в бухгалтерському обліку $i$ фінансовій звітності дебіторської заборгованості у відповідності до міжнародних стандартів. На практичному прикладі розглянуто, в який спосіб обліковий персонал має враховувати особливості МСФЗ 9 “Фінансові інструменти”, розкрито алгоритм розрахунку резерву під очікувані кредитні збитки при первісному визнанні фінансового інструменту, що обліковується за амортизованою вартістю.

Ключові слова: аудит, звітність, фінансовий актив, фінансовий інструмент, резерв.

Постановка проблеми. 301 січня 2018 року в Україні введено в дію Міжнародний стандарт фінансової звітності (МСФЗ) 9 "Фінансові інструменти”, який має такі складові:

- класифікація і оцінка фінансових активів і фінансових зобов'язань;

- знецінення фінансових активів;

- облік хеджування.

Зміни в МСФЗ спричинені тим, що ризики світової фінансової системи мають тенденцію до зростання, в результаті чого відображення в звітності фактів неплатоспроможності (дефолту) не задовольняє користувачів фінансової звітності, як то було реалізовано в МСБО 39. Їх цікавить імовірність отримання збитків у зв'язку 3 невиконанням контрагентом своїх договірних зобов'язань з моменту їх визнання.

Тому в МСФЗ 9 реалізовано нову модель оцінки очікуваних кредитних збитків (тобто збитків від того, що контрагент не розрахується за поставлені товари, роботи, послуги, надані кредити своєчасно або не розрахується взагалі), які є різницею між передбаченими угодою грошовими потоками і грошовими потоками, що очікуються до отримання.

Зважаючи на те, що обліковці та аудитори мають опанувати вимоги МСФЗ 9 щодо оцінки збитків від кредитних операцій, в статті на основі аналізу цих вимог запропоновано практичний приклад оцінки збитків від кредитних операцій, що обумовлює ії актуальність.

Аналіз наукових публікацій. Науковою проблематикою, пов'язаною з оцінкою фінансових активів, займалися так вчені як О. Редько, Т. Каменська, Н. Ботвіна [1], I. Горобець [2], I. Дмитренко, Н. Проскуріна, В. Пантелєєв, Ф. Харисова [3], О. Лубенченко [4]. Але питання обліку фінансових активів потребує подальшої уваги та більш досконалого вивчення.

Мета статті полягає у дослідженні вимог МСФЗ 9 щодо оцінки збитків від кредитних операцій та розробленні практичного прикладу застосування цього стандарту.

Результати дослідження. Класифікацію фінансових активів за МСФЗ 9 “Фінансові інструменти" наведено на рис. 1.

(C) О. М. Півньова, 2018 


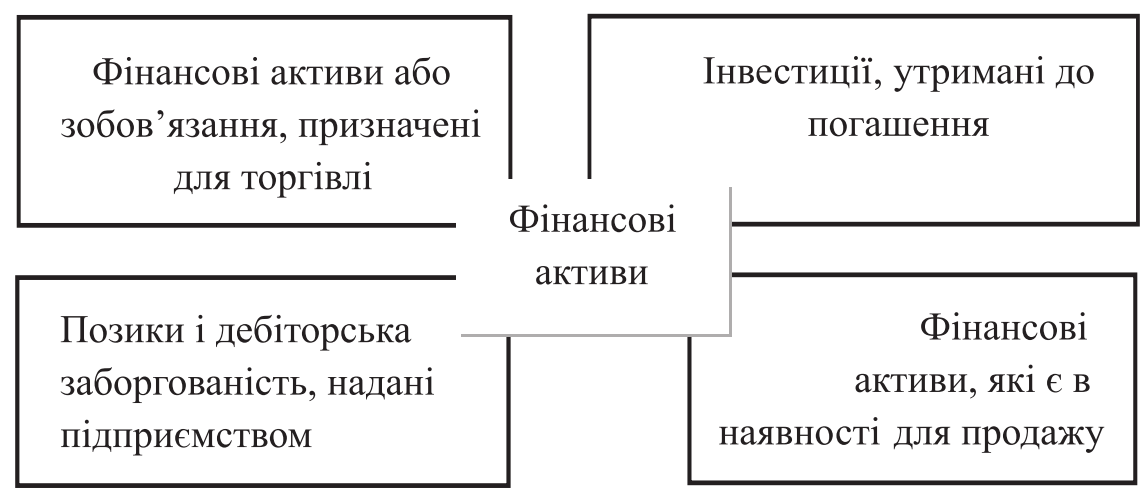

\section{Рис. 1. Класифікація фінансових активів за МСФ3 9 "Фінансові інструменти"}

Джерело: складено за МСФЗ 9 [5]

Первісне визнання фінансових інструментів у відповідності до МСФЗ має відбуватися в такій послідовності:

- згідно з обліковою політикою слід визнавати фінансовий актив або фінансове зобов'язання у балансі тоді, коли суб'єкт господарювання стає стороною за договором відносно фінансового інструменту. При первісному визнанні фінансового активу або фінансового зобов'язання обліковий персонал, а відповідно і зовнішній аудитор, при перевірці дебіторської та кредиторської заборгованості оцінюють його за фактичними витратами, тобто за справедливою вартістю внесеного (у випадку активу) або отриманого (у випадку зобов'язання) за нього відшкодування. Витрати після закінчення угоди включаються у первісну оцінку усіх фінансових активів та зобов'язань.

Подальша оцінка фінансових активів залежить від обраної в обліковій політиці класифікації об’єкта обліку:

- призначені для торгівлі активи оцінюються за справедливою вартістю (справедлива вартість активу залежить від ціни укладеної угоди або ринкових цін. У випадку, якщо ринкові ціни неможливо визначити з достатнім ступенем достовірності, справедлива вартість відшкодування розраховується як сума усіх майбутніх платежів або надходження грошових коштів, дисконтована (якщо це суттєво змінює отримані результати) за переважною ринковою ставкою відсотка для аналогічних операцій. У вітчизняній практиці, якщо не йдеться про пов'язані сторони, справедлива (ринкова) вартість є вартістю договору;

- позики та дебіторська заборгованість, а також інвестиції, утримані до погашення, відображаються амортизаційною вартістю;

- активи, які не мають фіксованого строку погашення, необхідно оцінювати за фактичними витратами [5].

Після первинного визнання також слід оцінити за справедливою вартістю:

- зобов'язання, призначенні для торгівлі,

- зобов'язання щодо похідних інструментів. вартістю.

Всі інші неторговельні фінансові зобов'язання обліковуються за амортизованою

На звітну дату та дату визнання слід визначати об'єктивні дані, що свідчать про знецінення активів (рис. 2). 


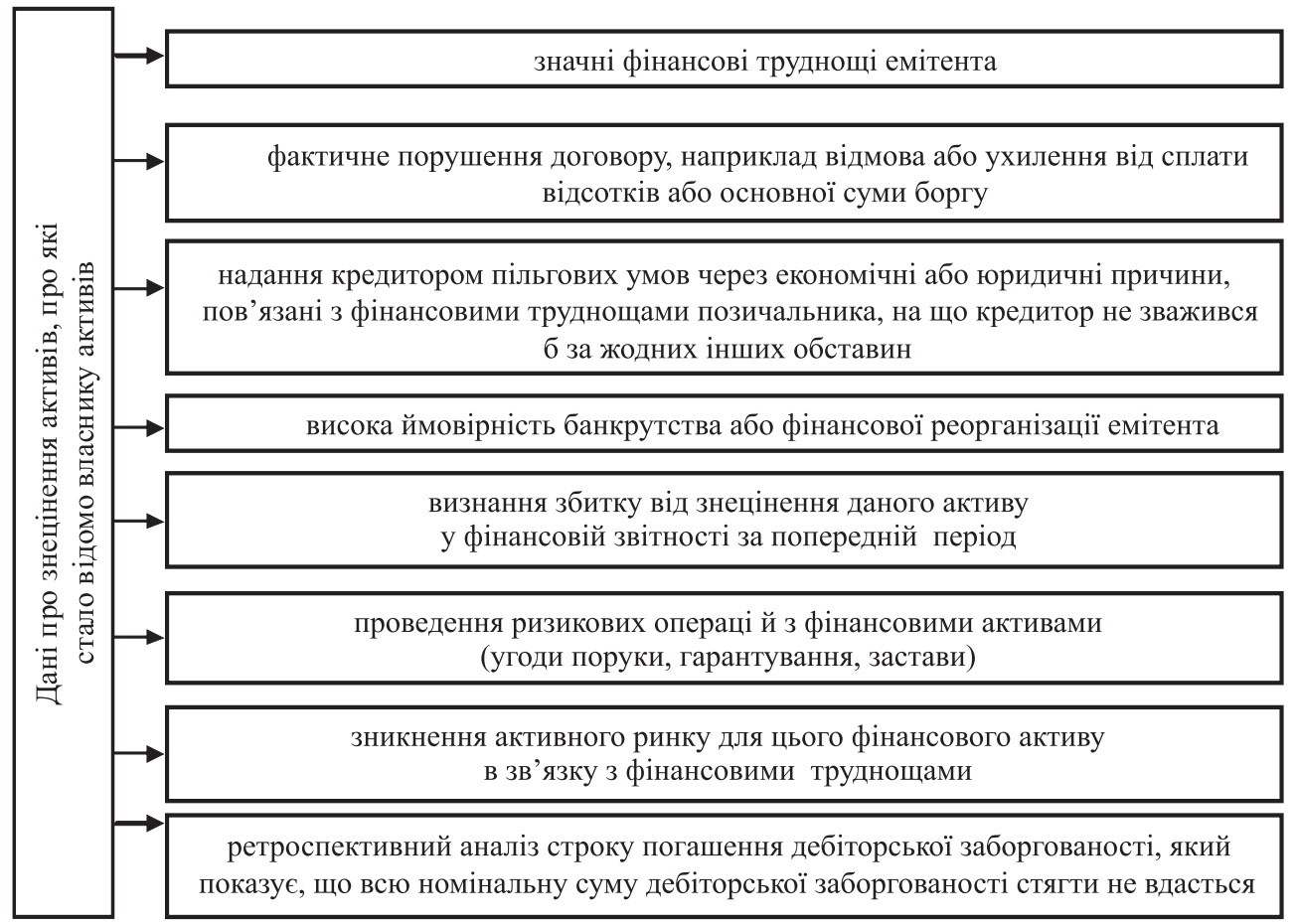

\section{Рис. 2. Узагальнені об’сктивні дані, що свідчать про знецінення фінансових активів}

Джерело: складено за МСФЗ 9 [5]

Методи обліку фінансових інструментів - інвестицій приведено на рис. 3.

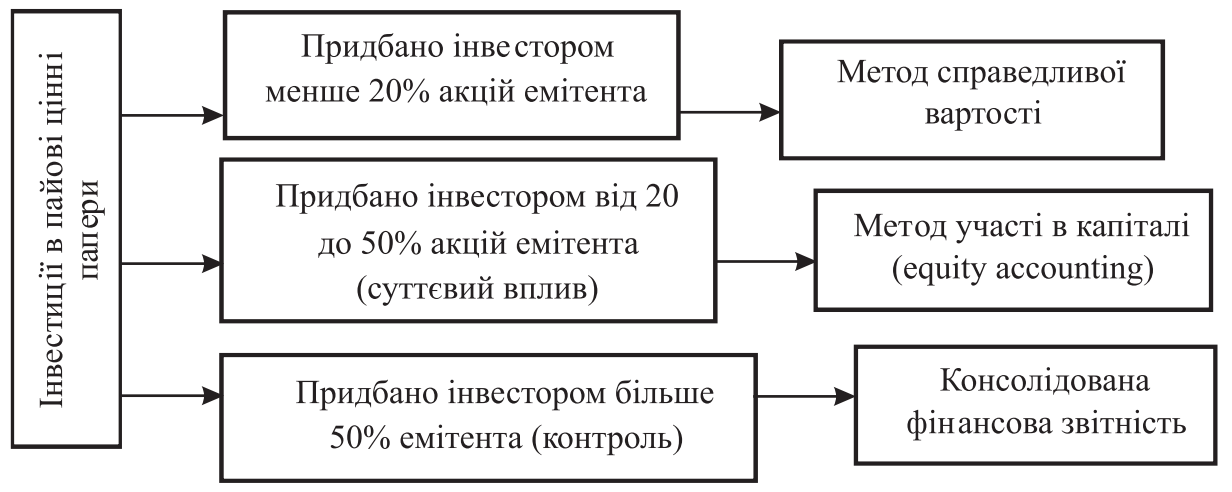

\section{Рис. 3. Метод обліку інвестицій \\ Джерело: складено за МСФ3 9 [5]}

Модель оцінки очікуваного знецінення фінансових активів на дату визнання представлено на рис. 4.

Згідно 3 п. 59 МСБО 39 корисність фінансового активу або групи фінансових активів зменшується і збитки від зменшення корисності виникають, якщо і тільки якщо є об'єктивне свідчення зменшення корисності внаслідок однієї або кількох подій, які відбулися після первісного визнання активу (“подія збитку”), і така подія (або події) збитку впливає (впливають) на попередньо оцінені майбутні грошові потоки від фінансового активу або групи фінансових активів, які можна достовірно оцінити. Може бути неможливим ідентифікувати одну окрему подію, що спричинила зменшення корисності. Скоріше поєднаний вплив кількох подій може спричинити зменшення 


\section{МІЖНАРОДНІ СТАНДАРТИ ФІНАНСОВОЇ ЗВІТНОСТІ ТА ЗНЕЦІНЕННЯ ФІНАНСОВИХ АКТИВІВ НА ПРИКЛАДІ КП “ЛУГАНСЬКИЙ ОБЛАСНИЙ ФОНД ПІДТРИМКИ...}

корисності. Збитки, очікувані як наслідок майбутніх подій, не визнаються незалежно від їх імовірності [5].

\begin{tabular}{|c|c|c|c|c|}
\hline \multirow{2}{*}{ 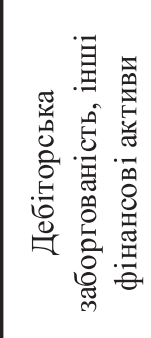 } & $\Rightarrow$ & $\begin{array}{c}\text { Облік за } \\
\text { амортизаційною } \\
\text { вартістю }\end{array}$ & $\begin{array}{l}\text { Дт рахунку “Витрати” } \\
\text { Кт “Резерв під очікувані } \\
\text { збитки від знецінення" }\end{array}$ & $\begin{array}{c}\text { Резерв } \\
\text { визнається у } \\
\text { складі активів }\end{array}$ \\
\hline & $\Rightarrow$ & $\begin{array}{c}\text { Облік за } \\
\text { справедливою } \\
\text { вартістю }\end{array}$ & $\begin{array}{l}\text { Дт рахунку “Витрати” } \\
\text { Кт “Власний капітал" }\end{array}$ & $\begin{array}{c}\text { Резерв } \\
\text { визнається у } \\
\text { складі власного } \\
\text { капіталу }\end{array}$ \\
\hline
\end{tabular}

\section{Рис. 4. Модель оцінки очікуваного знецінення фінансових активів на дату визнання}

Джерело: складено за МСФЗ 9 [5]

Такий самий підхід застосовується у МСФЗ 9 для поточної фінансової заборгованості. Порядок відображення в обліку резерву сумнівних боргів згідно з МСФЗ 9 представлено в табл. 1.

Таблиия 1

Порядок відображення в обліку резерву сумнівних боргів згідно з МСФ3 9

\begin{tabular}{|c|l|c|c|}
\hline $\begin{array}{c}\text { № } \\
\text { 3/п }\end{array}$ & \multicolumn{1}{|c|}{ Назва операції } & Дебет & Кредит \\
\hline $\mathbf{1}$ & Створення (нарахування резерву сумнівних боргів) & 944 & 38 \\
\hline $\mathbf{2}$ & $\begin{array}{l}\text { Списання безнадійної дебіторської заборгованості з активів } \\
\text { за рахунок резерву сумнівних боргів }\end{array}$ & 38 & 36 \\
\hline \multirow{2}{*}{$\mathbf{2}$} & $\begin{array}{l}\text { Списання безнадійної дебіторської заборгованості з активів } \\
\text { у сумі, що перевищує резерв }\end{array}$ & 944 & 36 \\
\hline \multirow{2}{*}{$\mathbf{2}$} & Корегування резерву сумнівних боргів на звітну дату: & \multicolumn{2}{|l|}{} \\
\cline { 2 - 4 } & збільшення & 944 & 38 \\
\cline { 2 - 4 } & зменшення (методом “сторно”) & 944 & 38 \\
\hline
\end{tabular}

Джерело: авторська розробка

Довгострокова дебіторська заборгованість в балансі має відображатися за дисконтною вартістю (рис. 5).

\begin{tabular}{|c|c|c|c|}
\hline \multirow[t]{2}{*}{$\mathrm{FV}=\mathrm{PV}(1+\mathrm{r})^{\mathrm{n}}$} & & \multicolumn{2}{|r|}{$\mathrm{PV}=\mathrm{FV} /(1+\mathrm{r})^{\mathrm{n}}=\mathrm{FV} \cdot\left[1 /(1+\mathrm{r})^{\mathrm{n}}\right]$} \\
\hline & \multicolumn{2}{|c|}{$\begin{array}{c}\text { Відсотки й } \\
\text { майбутня вартість }\end{array}$} & \\
\hline \multicolumn{2}{|c|}{$\begin{array}{l}\text { Майбутня вар тість - вартість } \\
\text { в майбутньому інвестованих } \\
\text { зараз грошових коштів }\end{array}$} & & $\begin{array}{l}\text { Дисконтована вартість- } \\
\text { тоточна (справжня) вартість } \\
\text { бутнього грошового потоку }\end{array}$ \\
\hline
\end{tabular}

\section{Рис. 5. Розрахунок майбутньої та дисконтованої вартості}

Джерело: складено за МСФЗ 9 [5]

Згідно з МСФЗ кредитний збиток від довгострокової дебіторської заборгованості це різниця між передбаченими договором грошовими потоками, які належать компанії, і грошовими потоками, які вона очікує отримати.

Якщо фактор часу істотний, то очікувані грошові потоки дисконтуються за первісною ефективною ставкою відсотка.

Ефективна ставка відсотка визначається як ставка, на основі якої здійснюється дисконтування очікуваного потоку майбутніх грошових платежів або надходжень упро- 
довж очікуваного терміну дії (існування) фінансового інструменту до чистої балансової вартості (амортизованої собівартості) цього фінансового інструменту.

Порядок знецінення, реалізований у МСФЗ 9, застосовується до фінансових активів, що обліковуються:

- за амортизаційною вартістю моделі ефективної ставки відсотка;

- $\quad$ за справедливою вартістю через інші сукупні доходи (крім інвестицій у дольові інструменти).

Фінансові інструменти, що підпадають під знецінення, зображено на рис. 6.

\begin{tabular}{|c|c|}
\hline \multirow{5}{*}{ 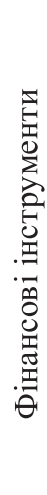 } & видані позики \\
\hline & дебіторська заборгованість (торговельна) \\
\hline & дебіторська заборгованість за фінансовою орендою \\
\hline & $\begin{array}{l}\text { інвестиції в боргові цінні папери, що утримуються для } \\
\text { отримання грошових потоків на рахунок погашення основної } \\
\text { суми боргу та відсотків }\end{array}$ \\
\hline & $\begin{array}{l}\text { інвестиції в боргові цінні папери, що утримуються для } \\
\text { отримання грошових потоків на рахунку погашення основної } \\
\text { суми боргу, відсотків, а також від їх продажу }\end{array}$ \\
\hline
\end{tabular}

Рис. 6. Фінансові інструменти, що підпадають під знецінення Джерело: складено за МСФЗ 9 [5]

Фінансові інструменти за МСФЗ 9, що не підпадають під порядок знецінення, представлено на рис. 7.

\begin{tabular}{|c|c|}
\hline 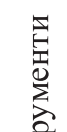 & $\begin{array}{l}\text { фінансові активи, що обліковуються за справедливою вартістю через } \\
\text { прибуток та збиток (іх оцін ку за справедливою вартістю Рада з МСФЗ } \\
\text { вважає достатньою) }\end{array}$ \\
\hline : & $\begin{array}{l}\text { інвестиції в дольові інструменти, що обліковуються за справедливою } \\
\text { вартістю через інший сукупний доход (не відповідають визначенню, } \\
\text { наведеному в п.4.1.2 та 4.1.2 А МСФ39, тому що не передбачають } \\
\text { отримання грошових коштів від контрагента) }\end{array}$ \\
\hline
\end{tabular}

\section{Рис. 7 Фінансові інструменти за МСФ3 9, що не підпадають під порядок знецінення}

Джерело: складено за МСФЗ 9 [5]

Механізм оцінки очікуваних кредитних збитків також застосовується для створення оціночних резервів під очікувані кредитні збитки за:

- зобов'язаннями надавати в майбутньому позики;

- договорами фінансової гарантії.

Порядок створення та подання резерву у фінансовій звітності відрізняється в залежності від того, як враховується фінансовий актив - за амортизованою або за справедливою вартістю через інший сукупний доход.

Якщо фінансовий актив обліковується за амортизованою вартістю, то оціночний резерв під очікувані кредитні збитки створюється за рахунок прибутків і збитків та зменшує балансову вартість фінансового активу в звіті про фінансовий стан:

Дт "Витрати” (прибутки та збитки);

Кт "Резерв під очікувані збитки від знецінення". 
У звіті про фінансовий стан такий резерв визнається в складі активів, зменшуючи тим самим балансову вартість фінансового активу.

Якщо фінансовий актив обліковується за справедливою вартістю через інший сукупний доход, то оціночний резерв під очікувані кредитні збитки також створюється за рахунок прибутків і збитків, але відноситься в кредит власного капіталу (через інший сукупний доход;

Дт “Витрати (прибутки та збитки)";

Кт “Накопичена сума знецінення (власний капітал)".

Це проведення також відображається в якості доходу в іншому сукупному капіталі.

Розглянемо, як відображаються у звітності витрати на очікувані кредитні збитки при первинному визнанні фінансового інструменту і в разі збільшення кредитного ризику.

Резерв під очікувані кредитні збитки розраховується при первісному визнанні фінансового інструменту. При первісному визнанні фінансового інструменту, а також на кожну звітну дату (якщо кредитний ризик значно не збільшився) суб'єкт господарювання має визнати резерв під очікувані кредитні збитки виходячи з ризику (ймовірності) настання дефолту позичальника протягом найближчих 12 місяців.

При цьому кредитний ризик - це ризик (ймовірність) настання дефолту (нездатності позичальника виконати прийняті на себе зобов'язання в установлені терміни).

Дефолт не обов'язково означає банкрутство позичальника. Згідно з МСФЗ 9 порушення терміну виконання зобов'язання (припустимо, обумовлений договором платіж був затриманий на 10 днів) також вважається дефолтом.

Вислів “оцінюється ймовірність настання дефолту протягом найближчих 12 місяців" не означає, що ми аналізуємо грошові потоки тільки протягом найближчих 12 місяців. Ми розглядаємо ймовірність настання дефолту позичальника протягом 12 місяців, а грошові потоки, пов'язані з цим дефолтом, відноситимуться до всього періоду дії договору.

В якості практичного спрощення цієї вимоги при первісному визнанні фінансового активу суб'єкт господарювання може розглядати ризики настання дефолту протягом усього терміну дії договору для:

- торгової дебіторської заборгованості та активів за договором (визнаних відповідно до МСФЗ (IFRS) 15 “Виручка за договорами з покупцями”);

- дебіторської заборгованості з оренди (визнана відповідно до МСФЗ (IAS) 17 "Оренда").

Такий порядок оцінки ризиків настання дефолтів повинен бути закріплений в обліковій політиці організації.

При значному збільшенні кредитного ризику суб’єкт господарювання має визнати резерв під очікувані кредитні збитки виходячи з ризику (ймовірності) настання дефолту позичальника протягом усього терміну дії договору.

Ознаками значного збільшення кредитного ризику є:

- значна зміна зовнішніх ринкових показників кредитного ризику (відсоткових ставок, курсів валют);

- значна зміна кредитного рейтингу фінансового інструменту або позичальника. Кредитний рейтинг може бути як зовнішнім (встановлюються рейтинговим агентством), так і внутрішнім (розрахованим за методикою самої організації);

- наявна або прогнозована несприятлива зміна технологічних, комерційних, фінансових або економічних умов, які можуть вплинути на позичальника (зростання безробіття, збільшення відсоткових ставок, зростання інфляції, зміна податкового законодавства);

- значна або очікувана зміна результатів операційної діяльності позичальника;

- значна зміна величини наданого забезпечення;

- $\quad$ прострочення встановлених договором платежів більш ніж на 30 днів.

При цьому стандарт не встановлює кількісних (відсоткових) значень поняття значного збільшення кредитного ризику. Така оцінка залежить від величини кредитного ризику при первинному визнанні. Припустимо, зміна кредитного ризику на один відсоток $є$ незначною, якщо кредитний ризик зріс із 30 до $31 \%$. Водночас збільшення кредитного ризику на один пункт із 3 до 4\% є істотним. На оцінку кредитного ризику 
впливає і термін погашення заборгованості. За інших рівних умов кредитний ризик за трирічною позикою більший, ніж за кредитом, виданим на один рік.

На кожну звітну дату організація оцінює резерв під очікувані кредитні збитки, відносячи в дебет рахунку прибутків та збитків суми збільшення резерву, а в кредит рахунку прибутків та збитків - суму зменшення резерву.

Величина резерву визначається шляхом зважування суми можливих кредитних збитків з урахуванням вартості грошей у часі.

При первинній оцінці сума резерву розраховується як різниця між зазначеною сумою платежів, встановленою в договорі, та припущеною сумою очікуваних до отримання платежів (зважених з урахуванням імовірності). Обидві суми дисконтуються за ринковою відсотковою ставкою.

Необхідність розрахунку саме за ринковою ставкою пов'язана з тим, що ефективну відсоткову ставку можна розрахувати тільки після визначення суми очікуваних до отримання платежів, що зважені на імовірність.

При подальшій оцінці сума резерву розраховується як різниця між валовою балансовою вартістю активу (тобто без урахування резерву) та сумою очікуваних платежів (з урахуванням імовірності) за первісною ефективною відсотковою ставкою.

При оцінці можливих збитків на кінець звітного періоду організація повинна використовувати обгрунтовану та підтверджену інформацію про минулі події, поточні та прогнозовані майбутні умови.

Робочий приклад знецінення фінансових активів, що обліковуються за амортизованою ціною, розроблено за обліковими даними КП “Луганський обласний фонд підтримки індивідуального житлового будівництва на селі” (КП “ФОНД ІЖБ”) та наведено нижче.

КП “ФОНД ІЖБ” готує звітність на 31 грудня кожного року. 30 грудня 2017 року КП “ФОНД ІЖБ”» надало позику ТОВ “Щедрий Лан” на трирічний термін на суму 10 млн грн за ринковою ставкою 8\% річних. Відповідно до умов договору ТОВ “Щедрий Лан" щорічно сплачує відсотки на 30 грудня. Позика повинна бути остаточно погашена 31 грудня 2020 року. КП “ФОНД ІЖБ” збирається утримувати цю позику до повного погашення згідно з МСФЗ 9. КП “ФОНД ІЖБ” оцінює ризик настання дефолту протягом найближчих 12 місяців таким чином:

- імовірність того, що ТОВ “Щедрий Лан” виявиться банкрутом і не зможе здійснити жодного з обумовлених у договорі платежів складає $1 \%$;

- імовірність того, що ТОВ “Щедрий Лан” не зможе виплачувати відсоткові платежі у встановлений договором термін, і вся сума відсотків буде повернена разом із позикою (12,4 млн грн) тільки 30 грудня 2020 року, складає 5\%.

30 грудня 2018 року КП “ФОНД ІЖБ” отримав від ТОВ “Щедрий Лан” встановлений договором відсотковий платіж у розмірі 800 тис. грн (10 млн грн. х 8\%).

Однак на 30 грудня 2018 року, за оцінками КП “ФОНД ІЖБ”, операційні результати ТОВ “Щедрий Лан” значно погіршилися. Ризик настання банкрутства ТОВ “Щедрий Лан" складає 6\%, а імовірність того, що відсотковий платіж на 30 грудня 2020 року буде перенесений на 30 грудня 2021 року, складає 10\%. Керівництво КП “ФОНД ІЖБ” оцінює ефективну відсоткову ставку за цією позикою у 8,42\% річних.

Розрахунок знецінення фінансових активів наведено в табл. 2.

\section{Розрахунок знецінення фінансових активів}

Таблиия 2

Ситуація регулюється МСФЗ 9 “Фінансові інструменти”

Рік закінчується 31.12.2017.

Видану позику необхідно обліковувати за амортизаційною вартістю за моделлю ефективної ставки відсотка, оскільки підприємство використовує бізнес-модель утримання позики задля отримання грошових коштів винятково за рахунок погашення відсотків та суми основного боргу.

Початкова оцінка позики - за справедливою вартістю.

3 моменту початкового визнання необхідно визнати резерв під очікувані кредитні збитки.

За первинною оцінкою сума резерву розраховується як різниця між приведеною сумою платежів, встановлених договором, і приведеною сумою очікуваних до отримання платежів (розрахованих із урахуванням ймовірності) за ринковою відсотковою ставкою (8\%). 
МІЖНАРОДНІ СТАНДАРТИ ФІНАНСОВӦ̈ ЗВІТНОСТІ ТА ЗНЕЦІНЕННЯ ФІНАНСОВИХ АКТИВІВ НА ПРИКЛАДІ КП “ЛУГАНСЬКИЙ ОБЛАСНИЙ ФОНД ПІДТРИМКИ...

\begin{tabular}{|c|c|c|}
\hline \multicolumn{3}{|c|}{ Розрахунок очікуваних до отримання платежів: } \\
\hline $\begin{array}{c}\text { Приведена сума очікуваних до } \\
\text { отримання платежів за ринковою } \\
\text { ставкою } 8 \% \text {, тис. грн }\end{array}$ & Імовірність, \% & Зважена сума, тис. грн \\
\hline 10000 & $94 \%$ & 9400 \\
\hline 0 & $1 \%$ & 0 \\
\hline $9846(12400 \times 0,794)$ & $5 \%$ & 462 \\
\hline \multicolumn{3}{|c|}{$\begin{array}{l}\text { Отже, приведена сума очікуваних до отримання платежів - } 989200 \text { тис. грн } \\
\text { Примітка: оскільки позика видана за ринковою ставкою, то приведена сума платежів, } \\
\text { вказаних в договорі, дорівнюватиме } 10000 \text { тис. грн. Це можна перевірити розрахунком: } \\
800 \text { тис. х } 0,926+800 \text { тис. х } 0,897+10800 \text { тис. х } 0,794 \text {. }\end{array}$} \\
\hline \multicolumn{3}{|c|}{ 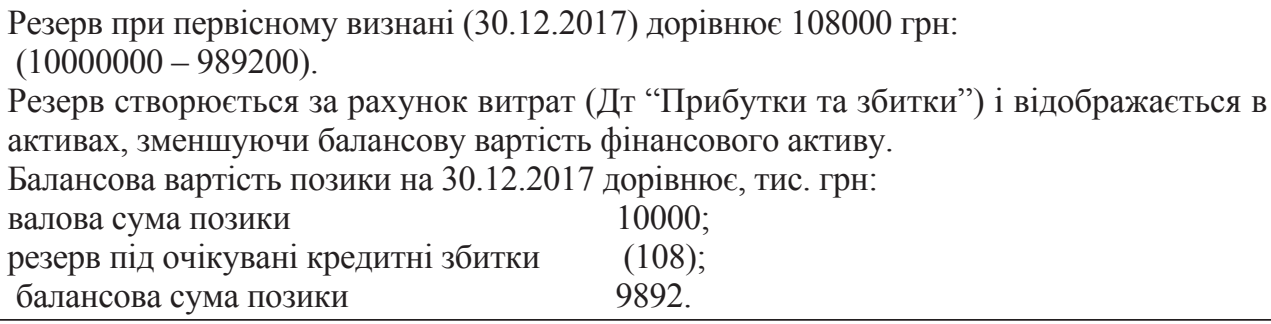 } \\
\hline \multicolumn{3}{|c|}{$\begin{array}{l}\text { Рік закінчується } 31.12 .2018 . \\
\text { Фінансовий актив амортизується за ефективною відсотковою ставкою }(8,42 \%) \text { з ура- } \\
\text { хуванням резерву під очікувані кредитні збитки. } \\
\text { Відсотковий доход відображається в прибутках та збитках. } \\
\text { Відсотковий доход за рік, який закінчився } 31.12 .2018 \text {, дорівнює } 833 \text { тис. грн } \\
(9892 \text { х } 8,42 \%) \text {. } \\
\text { Валова сума позики (без урахування резерву) на } 31.12 .2018 \text { року складає } 10033 \text { тис грн } \\
(10000 \text { тис. }+833 \text { тис. }-800 \text { тис.) }\end{array}$} \\
\hline
\end{tabular}

В наступному році оцінка суми резерву розраховується як різниця між валовою балансовою вартістю активу та приведеною сумою очікуваних платежів (зважену 3 урахуванням ймовірності) за первісною ефективною ставкою відсотка.

Розрахунок очікуваних до отримання платежів на 31.12.2018 p.

\begin{tabular}{|c|c|c|}
\hline $\begin{array}{l}\text { Приведена сума очікуваних до отримання платежів } \\
\text { за ефективною ставкою } 8,42 \% \text {, тис. грн }\end{array}$ & $\begin{array}{l}\text { Імовірність, } \\
\%\end{array}$ & $\begin{array}{l}\text { Зважена сума, } \\
\text { тис. грн }\end{array}$ \\
\hline $9928(10800 \times 0,851+800 \times 0,922)$ & $84 \%$ & 8340 \\
\hline 0 & $6 \%$ & 0 \\
\hline $9872(11600 \times 0,851)$ & $10 \%$ & 987 \\
\hline \multicolumn{3}{|c|}{ В результаті сума очікуваних до отримання платежів - 9327 тис. грн. } \\
\hline \multicolumn{3}{|c|}{$\begin{array}{l}\text { Резерв під очікувані кредитні збитки на } 31.12 .2018 \text { становить } 706 \text { тис. грн } \\
\text { (10033 тис. - } 9327 \text { тис.) } \\
\text { Витрати (Дт “Прибутки та збитки”) на створення резерву: } \\
598 \text { тис. ( } 706 \text { тис. }-108 \text { тис.) }\end{array}$} \\
\hline \multicolumn{3}{|c|}{$\begin{array}{ll}\text { Балансова вартість позики на 31.12.2018. } & \\
\text { валова сума позики } & 10033 \text { тис. грн; } \\
\text { резерв під очікувані кредитні збитки } & \text { (706 тис. грн); } \\
\text { балансова сума позики } & 9327 \text { тис. грн }\end{array}$} \\
\hline
\end{tabular}

Джерело: авторськая розробка

Виписку зі звіту КП “ФОНД ІЖБ” про сукупний доход за рік, який закінчився 31.12.2018, представлено в табл. 3 . 
Виписка зі звіту КП “ФОНД ІЖБ” про сукупний доход за рік, який закінчився 31.12.2018

\begin{tabular}{|l|c|c|}
\hline & 2018 & 2017 \\
\hline Прибутки та збитки & & \\
\hline Відсотковий доход & 833 & - \\
\hline Кредитні збитки (витрати на створення фонду) & $(598)$ & $(108)$ \\
\hline
\end{tabular}

Джерело: авторськая розробка

Виписку зі звіту КП “ФОНД ІЖБ” про фінансовий стан на 31.12.2018 р. представлено в табл. 4.

Таблиия 4

Виписка зі звіту КП “ФОНД ІЖБ” про фінансовий стан на 31.12.2018 р., тис. грн

\begin{tabular}{|l|c|c|}
\hline & 2018 & 2017 \\
\hline Довгострокові активи & & \\
\hline Позика & 9312 & 9892 \\
\hline Короткострокові активи & & \\
\hline Позики & 15 & - \\
\hline
\end{tabular}

Джерело: авторськая розробка

Відсотки, що характеризують стан дефолту, визначено виходячи з професійного судження облікового персоналу КП “ФОНД ІЖБ” (табл. 2).

Висновки. Робочий приклад знецінення фінансових активів, що обліковуються за амортизованою вартістю, розроблений за обліковими даними КП “ФОНД ІЖБ”, показує, що МСФЗ 9 надає змогу фінансовим установам реалізувати нову модель знецінення фінансових інструментів, сприяє достовірності обліку фінансових інструментів та задовольняє потреби користувачів фінансової звітності.

\section{Список використаних джерел}

1. Ботвіна Н. О. Хеджування валютного ризику як складова банківської безпеки. Економічний аналіз. 2013. Т. 14. № 2. С. 17-21.

2. Горобец И. В. Новшества в МСФО: хеджирование справедливой стоимости объекта [Электронний ресурс]. Аудит и консалтинг. URL: http://daic.com.ua/press-center/ nashi_publikatsii (Дата обращения: 29.10.2015).

3. Харисова Ф. И. Аудит производных финансовых инструментов. М.: Изд-во «Бухгалтерский учет», 2005. 136 с.

4. Лубенченко О. Е. Особливості аудиторської перевірки дебіторської і кредиторської заборгованості, яка обліковується за міжнародними стандартами // Науковий вісник Ужгородського університету. Серія: Економіка. 2016. № 1(47). Т. І. С. 464-468.

5. Міжнародний стандарт фінансової звітності 9“Фінансові інструменти” [Електронний ресурс]: Наказ Міністерства фінансів України від 01.01.2015 // Офіційний веб-сайт Міністерства фінансів України. URL: http://195.78.68.18/minfin/control/uk/publish/ article?showHidden $=1 \&$ art_id $=408113 \&$ cat_id $=408094 \&$ ctime $=1423500595988$.

\section{References}

1. Botvina N. O. (2013). Khedzhuvannia valiutnoho ryzyku yak skladova bankivskoi bezpeky [Hedging of the currency risk: a component of bank security]. Ekonomichnyi analiz - Economic analysis, 14 (2), 17-21 [in Ukrainian].

2. Gorobets I. V. Novshestva v MSFO: hedzhirovanie spravedlivoy stoimosti obiekta [Innovations in MSFR: hedging of the fair value of an object]. Audit $i$ konsalting - Audit and consulting. URL: http://daic.com.ua/press-center/nashi_publikatsii (Date of access: 29.10.2015) [in Russian]. 
3. Harisova F. I. (2005). Audit proizvodnyih finansovyih instrumentov [Audit of derivative financial instruments]. Moscow: "Buhgalterskiy uchet" [in Russian].

4. Lubenchenko O. E. (2016). Osoblyvosti audytorskoi perevirky debitorskoi i kredytorskoi zaborhovanosti, yaka oblikovuietsia za mizhnarodnymy standartamy [Specifics of audit of debtor and credit accounts recorded by international standards]. Naukovyi visnyk Uzhhorodskoho universytetu. Seriia: Ekonomika - Scientific bulletin of Uzhhorod University, Series: Economics. 1(47), I. 464-468 [in Ukrainian].

5. Mizhnarodnyi standart finansovoi zvitnosti 9"Finansovi instrumenty" [International standard of financial reporting 9 "Financial instruments"]: Resolution of the Ukrainian Ministry of Finance from 01.01.2015 // Official web-site of the Ukrainian ministry of Finance. URL: http://195.78.68.18/minfin/control/uk/publish/article?showHidden=1\&art $\mathrm{id}=408113 \&$ cat_id $=408094 \&$ ctime $=1423500595988$.

О. Н. ПИВНЕВА, магистрант

специальность "Учет и налогообложение", Национальна академия статистики, учета и аудита; Научный руководитель:

О. Э. Лубенченко, кандидат экономических наук, дочент, заведуюший Национальным иентром учета и аудита, Национальная академия статистики, учета и аудита

\section{Международные стандарты финансовой отчетности и обесценение финансовых активов на примере КП “Луганский областной фонд поддержки индивидуального жилищного строительства на селе”}

В статье рассмотрены особенности отражения в бухгалтерском учете и финансовой отчетности дебиторской задолженности в соответствии с международными стандартами. На конкретном примере рассмотрено, каким образом персонал должен учитывать особенности МСФО 9 “Финансовые инструментыл”, раскрыт алгоритм расчета резерва под ожидаемые убытки от кредитных операций при первоначальном признании финансового актива, который учитывается по амортизированной стоимости.

Ключевые слова: аудит, отчетность, финансовый актив, финансовый инструмент, резерв.

O. M. PIVNIOVA,

Master's Studens

Specialty "Accounting and Taxation",

National Academy of Statistics, Accounting and Audit; Research Supervisor:

O. E. Lubenchenko,

PhD (Economics), Associate Professor, Head of National Center of Accounting and Audit, National Academy of Statistics, Accounting and Audit

\section{International Standards of Financial Reporting and Devaluation of Financial Assets by Case of Communal Enterprise "Luhansk Regional Fund for Support of Individual Dwelling Construction and the Rural Area"}

International Standard of Financial Reporting (ISFR) 9 "Financial Instruments" was introduced in Ukraine on 01.01.2018. Bearing in mind that Ukrainian accountants and auditors are yet to learn the requirements of ISFR 9 on the assessment of losses from credit transactions, a practical example of assessing the losses from credit transactions 
is elaborated by scrutinizing these requirements. It is designed to help financial entities in implementing the new algorithm for devaluation of financial instruments, thus making the accounting of financial instruments more reliable and suitable for user needs. The following aspects are covered by the scrutiny and presented in image form: classification of financial assets by ISFR 9 "Financial Instruments", summing up of the objective data giving evidence of financial assets devaluation; the method for accounting of investment; assessment of the expected devaluation of financial assets on the date of the recognition; the procedure for recording the reserve of doubtful debts according to by ISFR 9; calculation of the future and discounted value; financial instruments subject to devaluation by ISFR 9; financial instruments not subject to devaluation by ISFR 9. A practical example illustrates the algorithm for calculating devaluated assets, the extract from the enterprise report (report of "Luhansk Regional Fund for Support of Individual Dwelling Construction and the Rural Area") on the total income, the extract from the enterprise report on the financial position as of the end of the year.

Keywords: audit, reporting, financial asset, financial instrument, reserve.

\section{Посилання на статтю:}

Півньова О. М. Міжнародні стандарти фінансової звітності та знецінення фінансових активів на прикладі КП “Луганський обласний фонд підтримки індивідуального житлового будівництва на селі” // Науковий вісник Національної академії статистики, обліку та аудиту: зб. наук. пр. 2018. № 1-2. С. 102-112. 